\title{
Penegakan Hukum dalam Tindak Pidana Pemerkosaan Terhadap Anak Berdasarkan Qanun Jinayat Aceh
}

\author{
Virdis Firmanillah Putra Yuniar \\ virdistvt@gmail.com \\ Universitas Airlangga
}

\begin{abstract}
Aceh Province is a province that gets legality from the central government to implement Islamic law. Law No. 11 of 2006 concerning the Government of Aceh was issued in order to strengthen and reinforce the application of Islamic Shari'a in Aceh. On September 27, 2014 the Aceh Legislative Assembly (DPRA) ratified a qanun-level legal product, namely Qanun No. 6 of 2014 concerning Jinayat Law. This jinayat Qanun has been implemented for more than one year. The problem is about how the position of the qanun is in the national legal system, how the linkages between law enforcement agencies and institutions that support the implementation of shari'ah in Aceh and what are the obstacles faced by each of these institutions. Not infrequently the special characteristics of this Qanun raise a number of problems that often deviate from the provisions, for example the use of the term personality, legal basis and material content. In reality, there is often sexual violence experienced by children as victims that can occur in a small environment, namely the family and can also occur within the community. In the case of the crime of rape of children in the Province of Nanggroe Aceh Darussalam there is little difference in practice because several cases can be applied different regulations, namely by using the Child Protection Law and Jinayat Qanun No.6 of 2014, among which regulations are dominant, which is more effective and acceptable to the community and how it will be handled in special areas of Aceh, will be discussed in this paper.
\end{abstract}

Keywords: Law Enforcement; Child Rape; Qanun Jinayat.

\begin{abstract}
Abstrak
Provinsi Aceh merupakan suatu provinsi yang mendapatkan legalitas dari pemerintah pusat untuk menerapkan syariat Islam. Undang-undang No. 11 Tahun 2006 Tentang Pemerintah Aceh diterbitkan dalam rangka memperkuat dan mempertegas penerapan syari'at Islam di Aceh . Pada tanggal 27 September 2014 Dewan Perwakilan Rakyat Aceh (DPRA) mensahkan satu produk hukum setingkat qanun, yaitu Qanun No. 6 Tahun 2014 Tentang Hukum Jinayat. Qanun jinayat ini sudah diberlakukan lebih dari satu tahun. Persoalannya adalah tentang bagaimana kedudukan qanun ini didalam sistem hukum nasional, bagaimana keterkaitan antar lembaga penegak hukum dengan lembaga-lembaga yang mendukung dalam pelaksanaan syari'at di Aceh serta apa saja kendala yang dihadapi oleh masing-masing lembaga tersebut. Tidak jarang karakteristik khusus Qanun ini memunculkan sejumlah permasalahan yang tidak jarang menyimpang dari ketentuan, misalnya penggunaan istilah asas personalitas, dasar hukum dan materi muatan. Dalam kenyataannya bahwa sering terjadi kekerasan seksual yang dialami oleh anak sebagai korban yang dapat terjadi dalam lingkungan kecil yaitu keluarga dan dapat pula terjadi dalam lingkungan masyarakat. Dalam perkara tentang tindak pidana pemerkosaan terhadap anak di Provinsi Nanggroe Aceh Darussalam memiliki sedikit perbedaan dalam prakteknya karena beberapa perkara dapat diterapkan peraturan yang berbeda yaitu dengan menggunakan Undang-undang Perlindungan Anak dan Qanun Jinayat No.6 Tahun 2014, diantara peraturan tersebut mana yang dominan berlaku, yang lebih efektif dan diterima dimasyarakat serta bagaimana penanganannya di daerah istimewa aceh akan dibahas dalam tulisan ini.
\end{abstract}

Kata Kunci: Penegakan Hukum; Pemerkosaan Anak; Qanun Jinayat. 


\section{Pendahuluan}

Dalam Sistem Pemerintahan Negara Kesatuan Republik Indonesia, Menurut UUD 1945 harus mengakui dan menghormati Pemda yang bersifat khusus atau istimewa dengan pemberian otonomi khusus, agar pemerintahan daerah dapat leluasa dalam mengelola pemerintahannya sendiri agar masyarakat lebih sejahtera.

Dalam Bab VI Undang-undang Dasar 1945 Tentang Pemerintah Daerah, pasal 18 ayat (5) menyebutkan bahwa pemerintah daerah menjalankan otonomi seluas-luasnya, kecuali urusan pemerintahan yang oleh Undang-undang ditentukan sebagai urusan pemerintah pusat, selanjutnya dalam ayat (6) disebutkan pula bahwa pemerintahan daerah berhak menetapkan peraturan daerah dan peraturan-peraturan lain untuk melaksanakan otonomi dan tugas pembantuan. Demikian juga dalam Undang-undang Dasar 1945 Pasal 18 B yang menyebutkan bahwa:

(1) Negara mengakui dan menghormati satuan-satuan pemerintahan daerah yang bersifat khusus atau bersifat istimewa yang diatur dengan Undang-undang.

(2) Negara mengakui dan menghormati kesatuan-kesatuan masyarakat hukum ada beserta hak-hak tradisionalnya sepanjang masih hidup dan sesuai dengan perkembangan masyarakat dan prinsip Negara Kesatuan Republik Indonesia, yang diatur dalam Undang-undang. ${ }^{1}$

Dalam syariat islam sendiri hukum pidananya mengatur tentang perbuatan pidana terhadap orang yang dapat mempertanggungjawbkan perbuatannya atau dapat disebut juga mukalaf yang paham nya diambil dari Al-Quran dan Hadist. Tentunya Hukum Pidana Islam ini bertujuan untuk kemaslahatan umat manusia dunia akhirat. Jinayah dalam hukum islam biasanya sering disebut juga dengan delik atau tindak pidana.

Hal istimewa yang dimiliki Aceh meliputi penyelenggaraan kehidupan beragama, adat, pendidikan dan peran ulama dalam penetapan kebijakan daerah. Hingga dibuatlah Qanun provinsi dalam rangka penyelenggaraan otonomi khusus yaitu Undang-undang Nomor 11 Tahun 2006 tentang Pemerintahan Aceh yang mengamanatkan pemberlakuan syariat Islam terhadap seluruh wilayah Provinsi Nangroe Aceh Darussalam (Pasal 16 ayat (2) huruf a).

\footnotetext{
1 Undang-Undang Dasar 1945.
} 
Pada Tahun 2002 pemerintah provinsi NAD memberlakukan syariat Islam bidang jinayah yaitu Qanun Nomor 11 Tahun 2002 tentang pelaksanaan Syariat Islam di bidang aqidah, ibadah dan syiar Islam. Qanun Nomor 12 Tahun 2003 tentang Minuman Khamar dan sejenisnya. Qanun Nomor 13 Tahun 2003 tentang maisir (judi), Qanun Nomor 14 Tahun 2003 tentang khalwat (perbuatan mesum).

Terhadap perbuatan mesum ini memiliki perhatian khusus karena merupakan atensi dari pihak-pihak internasional pada saat ini. Kekerasan seksual terhadap anak ini harus ditangani dengan serius karena kejahatan ini seringkali terjadi disekitar masyarakat dan semakin berkembang modus dari pelakunya. Perkembangan di Indonesia sendiritelah dibuktikan pembaruan dibidang hukum agar selalu mengikuti perkembangan yang ada dalam masyarakat jga, dapat terlihat dengan adanya beberapa kali perubahan terhadap undang-undang perlindungan anak khususnya dalam pasal terhadap kekerasan seksual yang ancaman hukumnya dinaikkan dan ditambah dengan adanya pemberatan tujuannya tidak lain adalah untuk menciptakan rasa perlindungan dan kepastian hukum bagi masyarakat khususnya anak yang menjadi korban.

Apabila seorang anak menjadi korban kejahatan maka untuk perlindungan hukumnya sudah tentu harus lebih diperhatikan karena anak-anak adalah generasi penerus bangsa. Untuk tindak pidana kekerasan seksual yang dialami oleh korban anak-anak sudah tentu memiliki efek trauma atau ingatan buruk yang dalam terhadap anak, ini mempengaruhi tingkah, pola hidup dan perilaku anak kedepannya.

Jaksa dalam hal melakukan penelitian terhadap berkas juga harus dapat melihat dan memilah pasal mana yang dapat didakwakan terhadap pelaku Tindak Pidana kejahatan seksual terhadap seorang anak, karena tidak semua kejahatan tersebut diatur dalam Qanun Jinayat seperti terhadap kasus Pencabulan. Untuk perbuatan cabul hanya diatur dalam Undang-undang Nomor 35 Tahun 2014.

Dalam Pembahasan terhadap Qanun jinayat ini diperlukan sebuah teori yang mendukung penerapan atas landasan konsep dalam penelitian dilapangan. Untuk penelitian ini penulis menggunakan "Teori Politik Hukum”. 
Mengenai pengertian politik hukum sudah banyak dikemukakan oleh para ahli hukum, seperti Mahfud MD yang mengemukakan bahwa politik hukum adalah legal policy atau garis (kebijakan) resmi tentang hukum yang akan diberlakukan dengan pembuatan hukum baru maupun menggantikan hukum lama guna mencapai tujuan negara. ${ }^{2}$

Menurut Padmo Wahyono politik hukum adalah kebijakan dasar yang menentukan arah, bentuk, maupun isi hukum yang akan dibentuk. ${ }^{3}$ Kata kebijakan ini memiliki keterkaitan dengan strategi yang sistematis, terperinci dan mendasar. Dalam merumuskan dan menetapkan hukum yang telah dan akan dilakukan, politik hukum inilah yang menyerahkan otoritas legislasi kepada penyelenggara negara, namun dengan tetap memperhatikan nilai yang berlaku di masyarakat selama ini, dan semuanya diarahkan dalam rangka mencapai tujuan negara yang dicita-citakan.

L.H.C Hullsman pernah mengemukakan bahwa sistem pemidanaan (the sentencing system) adalah aturan perundang-undangan yang berhubungan dengan sanksi dan pemidanaan (the statutory rules relating to penal sanctionand punishment). ${ }^{4}$

Sedangkan prof Barda dalam pengertian pidana yang lebih luas mencakup mengenai aturan-aturan tentang bagaimana hukum pidana itu dapat ditegakkan atau dioperasionalkan secara konkret sehingga seseorang dijatuhi sanksi (hukum pidana). Ini berarti semua aturan perundang-undangan mengenai hukum pidana substantif, hukum pidana Formal dan Hukum pelaksanaan pidana dapat dilihat sebagai satu kesatuan sistem pemidanaan. ${ }^{5}$

Qanun secara etimologis, berasal dari bahasa yunani yang masuk menjadi bahasa Arab melalui bahasa siryani yang artinya alat pengukur. Dalam bahasa inggris Qanun sendiri berarti canon dengan sinonim artinya dengan peraturan (regulation), hukum (law), norma (norm), Undang-undang (statue) dan peraturan dasar (basic rule).

\footnotetext{
${ }^{2}$ Mahfud Md, Politik Hukum di Indonesia, (Raja Grafindo Persada 2011). [1].

${ }^{3}$ Padmo Wahyono, Indonesia Negara Berdasarkan Atas Hukum (Ghalia Indonesia 1986).[160].

${ }^{4}$ Barda Nawawi Arief, Bunga Rampai Kebijakan Hukum Pidana (Citra Aditya Bakti 2002).[23].

5 ibid.[129].
} 
Berdasarkan Undang-undang no.11 Tahun 2016 tentang pemerintahan aceh, Pemerintahan Aceh diberikan beberapa kewenangan istimewa dalam mengurus daerahnya. Salah satu kewenangan yang dimiliki oleh pemerintah aceh adalah penerapan nilai-nilai syari'at Islam kepada masyarakat setempat yang diatur berdasarkan Qanun. Qanun juga mengatur tentang penyelenggaraan pemerintahan dan kehidupan masyarakat Aceh.

Kata Jinayah merupakan bentuk suatu kata verbal noun dari kata jana. Kata Jana memiliki arti berbuat dosa atau dapat juga memiliki arti yaitu salah. Orang yang berbuat salah disebut jani dan orang yang dikenai perbuatan atau korban disebutlah mujna'alaih. Kata Jinayah dalam istilah hukum sering disebut dengan delik atau tindak pidana. ${ }^{6}$

Untuk menjatuhkan sanksi pidananya tidak lepas dari teori pemidanaan yang dibagi menjadi 3 (tiga) kelompok yaitu:

a. Teori absolut atau Teori Pembalasan

Menurut teori ini pidana yang dijatuhkan adalah berasal dari pemikiran karena orang telah melakukan suatu kejahatan atau tindak pidana. Pidana merupakan akibat mutlak yang dirasa harus ada sebagai suatu pembalasan kepada orang yang melakukan kejahatan. Jadi dapat dikatakan dasar pembenaran dari pidana terletak pada adanya atau terjadinya kejahatan yang telah dilakukan oleh seseorang.

b. Teori Relatif atau Teori Tujuan

Terhadap pemberian sanksi pidana, dimaksudkan untuk menimbulkan efek jera secara langsung supaya si pelaku tidak melakukan pelanggaran berulang kali. Efek langsung yang bisa ditimbulkan bisa saja berupa rasa sakit ataupun rasa malu, dan jika pidana tersebut dilakukan di depan khalayak ramai sebagai pelajaran baik terhadap pelaku serta rasa takut bagi masyarakat ataupun calon pelaku lainnya untuk tidak melakukan hal atau kejahatan yang serupa. Teori ini berpokok pangkal pada dasar bahwa pidana adalah alat untuk menegakkan tata

6 Zulkarnain Lubis dan Bakti Ritonga, Dasar-Dasar Hukum Acara Jinayah (Prenamedia Grup 2016).[2]. 
tertib dalam masyarakat dan dalam menegakkan tata tertib itu diperlukan pidana. Dalam teori ini pidana adalah alat untuk mencegah timbulnya suatu kejahatan, dengan tujuan agar tata tertib masyarakat tetap terpelihara. ${ }^{7}$

c. Teori Gabungan

Teori ini membuat suatu kombinasi yaitu antara teori absolut dengan teori relatif, dimana dalam teori ini memiliki anggapan bahwa pemidanaan di samping merupakan konsekuensi terhadap dilakukannya suatu kejahatan juga untuk mempertahankan tata tertib yang ada di masyarakat.

\section{Qanun Aceh Dalam Sistem Hukum Nasional}

Provinsi mendapatkan legalitas dari pemerintah pusat dalam penerapan syariat Islam. Undang-undang No. 11 Tahun 2006 Tentang Pemerintah Aceh diterbitkan juga tidak lain adalah dalam rangka memperkuat dan mempertegas penerapan syari'at Islam di Aceh . Dewan Perwakilan Rakyat Aceh mengesahkan produk hukum pada tanggal 27 September 2014 produk itu adalah Qanun Jinayat, yang tidak lain dikenal dengan Qanun Aceh Nomor 6 Tahun 2014. Qanun jinayat ini sudah diberlakukan lebih dari satu tahun. Persoalannya adalah tentang bagaimana kedudukan qanun ini didalam sistem hukum nasional, bagaimana keterkaitan antar lembaga penegak hukum dengan lembagalembaga yang mendukung dalam pelaksanaan syari'at di Aceh serta apa bentuk konkrit tentang kendala dan hambatan yang dihadapi oleh masing-masing lembaga tersebut. Tidak jarang karakteristik khusus Qanun ini memunculkan sejumlah permasalahan yang tidak jarang menyimpang dari ketentuan, misalnya terhadap penggunaan istilah asas personalitas, dalam dasar hukum dan tentang materi muatan.

Kebijakan pidana dalam Qanun Aceh merupakan salah satu wujud akomodasi yang ideal dalam pembangunan hukum, sebab pembangunan hukum nasional harus berwawasan nasional satu kesatuan atau unifikasi, dan demi keadilan harus diperhatikan wawasan bhineka tunggal ika yang menghormati latar belakang sosial budaya yang berbeda namun tetap mengutamakan kepastian hukum.

${ }^{7}$ Adami Chazawi, Pelajaran Hukum Pidana (Raja Grafindo 2001).[158]. 
Terhadap penyerahan otonomi khusus ini juga dilatarbelakangi oleh dua hal, yaitu konflik yang ada dalam provinsi aceh serta yang ada dalam tingkat nasional yang meliputi juga hubungan antara pemerintah pusat dengan pemerintah daerah provinsi Aceh.

Dalam sistem Pemerintahan Negara Indonesia dalam UUD 1945 telah mengakui adanya otonomi khusus, hal ini tidak lain diberikan adalah agar pemerintah daerah dalam melaksanakan tugas dan kewajibannya dapat lebih leluasa dalam menentukan kebijakan juga terutama. Di pasal 18 ayat 15 telah diatur hal tersebut dan dalam pasal 6 nya pemerintah juga berhak menetapkan suatu Perda.

Pengertian Qanun sendiri dalam Kamus Besar Bahasa Indonesia dikenal dengan nama: Kanun, yang artinya adalah : undang-undang, peraturan, kitab undang-undang, hukum dan kaidah. Adapun pengertian Qanun menurut kamus Bahasa Arab adalah: undang-undang, kebiasaan atau adat. ${ }^{8}$ Jadi dapat disimpulkan bahwa pengertian dari Qanun adalah : suatu peraturan perundang-undangan atau aturan hukum yang berlaku di suatu daerah (dalam hal ini di NAD).

Ketentuan tentang Qanun terdapat di dalam UU No.11 Tahun 2006 tentang Pemerintahan Aceh, yaitu: 1. Qanun Aceh adalah : peraturan perundang-undangan sejenis peraturan daerah provinsi yang mengatur penyelenggaraan pemerintahan dan kehidupan masyarakat Aceh. ${ }^{9}$ 2. Qanun kabupaten/kota adalah peraturan perundang-undangan sejenis peraturan daerah kabupaten/kota yang mengatur penyelenggaraan pemerintahan dan kehidupan masyarakat kabupaten/kota di Aceh. ${ }^{10}$ Bila dilihat ketentuan kedua Pasal di atas, dapat disimpulkan bahwa maksud dari Qanun ini juga disamakan dengan Peraturan Daerah seperti halnya Provinsi lain yang ada di Indonesia, tetapi pada dasarnya pemahaman Qanun yang disamakan dengan Peraturan daerah sesungguhnya juga tidaklah tepat. Qanun merupakan suatu peraturan perundang-undangan yang diberlakukan di NAD yang isinya harus dilandaskan pada syariat Islam yang menjadi suatu kekhususan dari NAD, hal ini

\footnotetext{
8 Mahmud Yunus, Kamus Arab-Indonesia (Hidakarya Agung 1989).[357].

9 Pasal 1 angka 21 UU No. 11 Tahun 2006.

${ }^{10}$ Pasal 1 angka 22 UU No. 11 Tahun 2006.
} 
juga memiliki perbedaan dengan daerah lain yang aturan-aturan dalam Perdanya tidaklah harus berlandaskan tentang ajaran-ajaran Islam. Selain hal tersebut qanun juga berbeda dengan Perda lainnya di Indonesia, aturan-aturan Qanun dapat berisikan mengenai aturan-aturan hukum tentang hukum acara baik dari segi material maupun formilnya di Mahkamah Syar'iah.

Kedudukan Qanun dipersamakan dengan Perda di daerah lainnya. Menurut UU No.10 Tahun 2004 disebutkan bahwa: ${ }^{11}$ jenis maupun hierarki peraturan perundang-undangan adalah sebagai berikut: UUD RI Tahun 1945, UU/ Peraturan Pemerintah Pengganti UU, Peraturan Pemerintah, Peraturan Presiden dan Peraturan Daerah. Pada penjelasan Pasal 7 disebutkan bahwa: Dapat juga Termasuk dalam jenis-jenis peraturan daerah provinsi adalah Qanun yang berlaku di Daerah Provinsi Nanggroe Aceh Darussalam dan Perdasus serta Perdasi yang berlaku atau hidup di Provinsi Papua.

Apabila kita ambil ketentuan di atas, maka kedudukan Qanun diakui dalam hierarki perundang-undangan Indonesia dan dapat dipersamakan kedudukannya dengan Perda. Pengakuan tersebut memiliki arti bahwa qanun diakui keberadaannya dan mempunyai kekuatan hukum mengikat, sejalan dengan Pasal 8 ayat (2) dalam Undang-undang Nomor 12 Tahun 2011 secara tidak langsung menerangkan bahwa kemunculan qanun ini diperintahkan oleh Peraturan Perundang-undangan yang lebih tinggi atau dibentuk berdasarkan kewenangan. Pemahaman dalam UU No. 10 Tahun 2004 ini tentu dapat saja diterima dalam hal kedudukan Qanun. Pemahaman ini secara eksistensi akan lebih mempermudah Pemerintah Pusat dalam hal melakukan pengawasan dan pembinaan terhadap daerah, terutama yang berhubungan dengan pembentukan suatu kebijakan daerah. Hanya saja tetap harus diperhatikan tentang kekhususan yang diberikan Pusat terhadap NAD. Contohnya saja, berdasarkan kekhususan yang di berikan Pusat kepada NAD, maka DPR Aceh dapat mensahkan Qanun tentang jinayat atau peradilan pidana Islam sebagai hukum acara di Mahkamah Syar'iah. Hanya saja memang produk dari Qanun ini harus 
memenuhi syarat-syarat yang harus dipenuhi oleh Pemerintahan Aceh seperti tidak boleh bertentangan dengan: aqidah, syar'iyah dan akhlak yang dalam penjabarannya meliputi: ibadah, ahwal al-syakhshiyah (hukum keluarga), muamalah (hukum perdata), jinayah (hukum pidana), qadha' (peradilan), tarbiyah (pendidikan), dakwah, syiar dan pembelaan Islam. ${ }^{12}$ Kebijakan ini tentu tidak diperbolehkan dibuat oleh perda-perda lainnya di Indonesia.

Dalam rangka menunjang efektivitas qanun Aceh ini pihak Kejaksaan di Aceh tetap komitmen untuk menjalankan Qanun Hukum Jinayat secara menyeluruh sesuai aturan yang ada. Sebagaimana yang telah diungkapkan oleh Kajati Aceh "Kita tidak akan pandang buku dalam penegakan hukum syariat Islam. Itu sudah komitmen kejaksaan di Aceh, juga bagi non muslim yang melanggar qanun." ${ }^{13}$ Selain itu pihak Kejaksaan juga berkoordinasi dengan lembaga-lembaga penegak hukum syariat lain seperti Wilayatul Hisbah (WH), hakim Mahkamah Syar'iyah, Kepolisian, dan juga Dinas Syariat Islam Aceh agar implementasi Qanun minim akan kendala.

\section{Dinas Syariat Islam}

Visi dan misi utama dibentuknya Dinas Syariat Islam adalah untuk terwujudnya masyarakat Aceh yang adil dan makmur serta bermartabat dalam tuntunan syariat Islam secara kaffah. Hal ini dapat dilaksanakan dengan menyebarluaskan informasi mengenai syariat Islam, menyiapkan, mensosialisasikan qanun dan peraturan tentang pelaksanaan syariat Islam. Menyiapkan dan membina sumber daya manusia pelaksana dan pengawas pelaksanaan syariat Islam, melakukan pembinaan dan memantapkan kesadaran umat, pengamalan ibadat serta penyemarakan syiar tentang keagamaan dan juga membantu mewujudkan pengadilan yang bersifat jujur, adil, mengayomi, berwibawa serta mudah, murah dan cepat yang semuanya berlandaskan syariat Islam.

\footnotetext{
12 Pasal 125 UU no. 11 Tahun 2006

${ }^{13}$ Hasyim, 'Qanun Jinayat Berlaku Untuk Semua Orang Di Aceh' (Serambinews.com, 2014) $<$ https://aceh.tribunnews.com/2014/04/19/qanun-jinayat-berlaku-untuk-semua-orang-di-aceh> accessed 1 January 2019.
} 


\section{Wilayatul Hisbah}

Wilayatul Hisbah merupakan satu badan pengawasan yang berfungsi melakukan amar ma'ruf nahi munkar, mengingatkan selalu kepada masyarakat mengenai aturan-aturan syari'at yang berlaku, tidak lupa juga mengenai langkah yang harus mereka ambil untuk menjalankan syari'at islam serta menunjukkan batas di mana orang-orang harus berhenti. Karena apabila mereka terus melakukan perbuatan itu maka mereka akan dianggap melanggar ketentuan syariat. Dalam keadaan terpaksa atau sangat mendesak, WH diberi izin melakukan tindakan untuk menghentikan pelanggaran serta melakukan tindakan yang juga dapat menghentikan upaya pelanggaran ataupun sebaliknya WH juga turut mengarahkan orang-rang untuk dekat atau ikut dalam koridor ajaran dan perintah syariat.

\section{Lembaga Kepolisian}

Sesuai dengan Undang-undang No. 2 Tahun 2002 tentang Kepolisian Republik Indonesia khususnya pasal 13 disebutkan bahwa tugas pokok Polri adalah memelihara keamanan dan ketertiban masyarakat, penegakan hukum, melindungi, melayani dan mengayomi masyarakat. ${ }^{14}$

Untuk menunjang kinerja kepolisian dalam melaksanakan tugasnya maka dalam hal ini Gubernur Provinsi Aceh diteetapkan Qanun Nomor 11 Tahun 2004.

\section{Lembaga Kejaksaan}

Peran Jaksa dalam pelaksanaan Qanun Provinsi Aceh tentunya juga sebagai eksekutor sesuai dengan tugas jaksa dalam KUHAP dan UU No. 16 Tahun 2004 yaitu melaksanakan putusan pengadilan yang telah memperoleh kekuatan hukum tetap. Jaksa juga sebagai eksekutor dalam melaksanakan hukuman cambuk terhadap perkara Qanun.

\footnotetext{
${ }_{14}$ Undang-undang No. 2 Tahun 2002 tentang Kepolisian Republik Indonesia. Lembaran negara Republik Indonesia Tahun 2002 Nomor 2.
} 


\section{Mahkamah Syar'iyah}

Mahkamah syar'iyah kabupaten/kota memiliki kewenangan untuk mengadili segala perkara mngenai jarimah yang dilakukan jika itu masih dalam wilayah hukumnya. Di Pasal 92 Hukum Acara Jinayat dalam hal upaya hukum banding mahkamah syar'iyah Provinsi Aceh lah yang berwenang mengadili perkara tersebut. Sedangkan dalam pasal 236 Hukum Acara Junayat menerangkan bahwa terhadap putusan uqubat yang telah di putus oleh Mahkamah syar'iyah Aceh apabila pihak terdakwa maupun penuntut umum menolaknya, maka tetap dapat mengajukan upaya hukum kasasi kepada Mahkamah Agung dengan tetap berpedoman pada peraturan Mahkamah Agung, kecuali untuk putusan bebas.

\section{Tindak Pidana Pemerkosaan Menurut Kitab Undang-Undang Hukum Pidana dan Undang-Undang Perlindungan Anak.}

Beban psikis yang dirasakan oleh korban memiliki dampak terhadap kehidupannya. Maka dari itu negara telah memberikan payung hukum terhadap tindak pidana kekerasan seksual terhadap anak yang tercantum dalam pasal 287 KUHP berbunyi: ${ }^{15}$

Barang siapa bersetubuh dengan seorang wanita di luar perkawinan, padahal diketahuinya atau sepatutnya harus diduganya bahwa umurnya belum lima belas tahun, dan kalau umurnya tidak jelas, bahwa belum waktunya untuk dikawin, diancam dengan pidana penjara paling lama sembilan tahun.

Pada pasal 287 KUHP diatur juga mengenai pemberatan hukuman pidana dalam pasal 291 ayat (1) dengan pidana penjara paling lama 12 tahun jika terjadi lukaluka berat, sedangkan dalam ayat (2) apabila mengakibatkan kematian maka pidana yang dijatuhkan terhadap pelaku paling lama adalah 15 tahun

Dalam pengaturannya terhadap tindak pidana pemerkosaan ada pada pasal 81 Undang-undang Nomor 23 Tahun 2002 tentang perlindungan anak dalam ayat 1 yang berbunyi:

"Setiap orang yang dengan sengaja melakukan kekerasan atau ancaman

${ }^{15}$ Kitab Undang-Undang Hukum Pidana 
kekerasan memaksa anak melakukan persetubuhan dengannya atau dengan orang lain, dipidana dengan penjara paling lama 15 (lima belas) tahun dan paling singkat 3 (tiga) tahun dan denda paling banyak Rp.300.000.000,00 (tiga ratus juta rupiah) dan paling sedikit Rp.60.000.000,00 (enam puluh juta rupiah)". ${ }^{16}$

Apabila dilihat dari sanksi yang dijatuhkan terhadap pelaku tindak pidana kejahatan seksual tersebut dinilai belum cukup memiliki efek jera terhadap pelaku. Hal ini dapat dilihat dari makin maraknya tindak pidana kejahatan seksual terhadap anak yang terjadi di masyarakat, belum lagi terdapat juga kejahatan seksual yang cukup banyak dilakukan oleh orang-orang terdekat dari sang anak. Sehingga, berdasarkan paradigma tersebut maka Undang-undang Nomor 23 Th 2002 tentang perlindungan anak akhirnya diubah dengan undang-undang No. 35 Th 2014 tentang perubahan atas undang-undang No. 23 tahun 2002 tentang perlindungan anak, yang mempertegas tentang perlunya pemberatan sanksi pidana dan denda pelaku kejahatan seksual terhadap anak. Hal ini dapat dilihat dalam pasal $81 \mathrm{UU}$ Perlindungan Anak tahun 2014 sebagai berikut: ${ }^{17}$

(1) setiap orang yang melanggar ketentuan sebagaimana dimaksud dalam pasal $76 \mathrm{D}$ dipidana dengan pidana penjara paling singkat 5 (lima) tahun dan paling lama 15 (lima belas) tahun dan denda paling banyak Rp. 5.000.000.000,00 (lima milyar rupiah).

(2)Ketentuan pidana sebagaimana dimaksud pada ayat (1) berlaku pula bagi Setiap Orang yang dengan sengaja melakukan tipu muslihat, serangkaian kebohongan, atau membujuk anak melakukan persetubuhan dengannya atau dengan orang lain.

(3)Dalam hal tindak pidana sebagaimana dimaksud pada ayat (1) dilakukan oleh orang tua, wali, pengasuh anak, pendidik atau tenaga kependidikan, maka pidananya ditambah $1 / 3$ (sepertiga) dari ancaman pidana sebagaimana dimaksud pada ayat (1).

\footnotetext{
${ }^{16}$ UU No.23 Th. 2002 Tentang Perlindungan Anak

17 Pasal 81 UU no. 35 Th 2014 Tentang Perubahan atas Undang-undang no.23 Tahun 2002 Tentang Perlindungan Anak
} 
Pasal 76 D dalam isinya adalah mengenai setiap orang dilarang melakukan kekerasan atau ancaman kekerasan memaksa anak untuk melakukan persetubuhan dengannya atau dengan orang lain. Dapat dilihat terdapat perbedaan tuntutan hukuman bagi pelaku kekerasan seksual terhadap anak pada UU No.23 Th 2002 yang hanya diberi hukuman minimal 3 (tiga) tahun, dan maksimal 15 (lima belas) tahun dan dengan denda maksimal Rp.60.000.000 (enam puluh juta rupiah), sedangkan dalam UU No. 35 Th 2014 diubah dengan ancaman pidana minimal 5 (lima) tahun dan maksimal 15 (lima belas) tahun serta denda maksimal sebanyak Rp.5.000.000.000 (lima milyar rupiah).

\section{Tindak Pidana Pemerkosaan dalam Qanun Aceh Nomor 6 Tahun 2014 Tentang Hukum Jinayat}

Qanun hukum jinayat memberikan definisi pemerkosaan sebagai hubungan seksual terhadap faraj atau dubur orang lain sebagai korban dengan zakar pelaku atau benda lainnya yang digunakan pelaku dengan kekerasan atau paksaan atau ancaman terhadap korban.

Menurut aturan pada pasal 52 Qanun Hukum Jinayat ini merupakan delik aduan bukan pelaporan karena pembebanan kewajiban dalam hal menyertakan alat bukti permulaan terhadap korban dan permintaan tindak lanjut terhadap kasus oleh korban sedangkan dalam hal pelaporan korban hanya melapor saja tanpa ada keinginan untuk tindakan selanjutnya dari pihak yang berwenang.

Terdapat beberapa permasalahan lain dalam kenyataannya di lapangan yang dialami oleh aparat penegak hukum khususnya bagi penuntut umum, yakni terhadap pasal 52 ayat (3) dan (4) dalam hal penyidik pada akhirnya menemukan alat bukti tetapi tidak memadai, orang yang mengaku diperkosa tersebut dapat mengajukan sumpah sebagai alat bukti tambahan untuk menyempurnakannya. Penyidik dan jaksa penuntut umum kemudian meneruskan perkara kepada tersebut kepada Mahkamah Syar'iyah dengan adanya bukti permulaan serta pernyataan kesediaan orang yang mengaku diperkosa untuk kemudian bersumpah di hadapan hakim. 
Apabila terdapat perkara bebas, penuntut umum tentu akan dinilai kurang profesional dan kurang cermat dalam menangani perkara dalam hal mempelajari dan meneliti berkas perkara. Bila perkara tersebut di eksaminasi atau dilakukan pemeriksaan perkara, maka akan terlihat suatu ketidakmampuan jaksa mempelajari berkas secara baik hingga masuk ke proses persidangan dan perkara tersebut bebas. Bila terjadi kesalahan tersebut murni kesalahan itu ada pada jaksa penuntut umum. Karena kondisi alat bukti yang terdapat di berkas belum memadai dan belum bisa untuk di bawa ke persidangan namun dinyatakan lengkap. ${ }^{18}$

Adapun dalam BAB IV bagian ketujuh tentang jarimah dan uqubah, pemerkosaan diatur dalam pasal 48, 49, dan 50 yang menyebutkan:

Pasal 48:

"Setiap orang yang dengan sengaja melakukan jarimah pemerkosaan diancam dengan 'uqubat ta'zir cambuk paling sedikit 125 (seratus dua puluh lima) kali, paling banyak 175 (seratus tujuh puluh lima) kali atau denda paling sedikit 1.250 (seribu dua ratus lima puluh) gram emas murni, paling banyak 1750 (seribu tujuh ratus lima puluh) gram emas murni atau penjara paling singkat 125 (seratus dua puluh lima) bulan, paling laa 175 (seratus tujuh puluh lima) bulan".

Pasal 49

"Setiap orang yang dengan sengaja melakukan jarimah pemerkosaan terhadap orang yang memiliki hubungan mahram diancam dengan 'uqubat ta'zir cambuk paling sedikit 150 (seratus lima puluh) kali, paling banyak 200 (dua ratus) kali atau denda paling sedikit 1.500 (seribu lima ratus) gram emas murni, paling banyak 2000 (dua ribu) gram emas murni atau penjara paling singkat 150 (seratus lima puluh) bulan, paling lama 200 (dua ratus) bulan."

Pasal 50:

"Setiap orang yang dengan sengaja melakukan jarimah pemerkosaan sebagaimana dimaksud dalam pasal 48 terhadap anak diancam dengan 'uqubat ta'zir cambuk paling sedikit 150 (seratus lima puluh) kali, paling banyak 200 (dua ratus) kali atau denda paling sedikit 1.500 (seribu lima ratus) gram emas murni, paling banyak 2000 (dua ribu) gram emas murni atau penjara paling singkat 150 (seratus lima puluh) bulan, paling lama 200 (dua ratus) bulan”.

\footnotetext{
${ }^{18}$ Amrizal Tahar, Kepala Kejaksaan Negeri Aceh Singkil, wawancara tanggal 15 Februari
} 2019. 


\section{Hukum Formil Dalam Qanun Aceh Tentang Hukum Jinayat}

Polisi dan Jaksa harus dapat berkoordinasi untuk menanggulangi kejahatan yang terjadi di masyarakat. Dalam hukum acara pidana di Indonesia bila dilihat dari sejarahnya pada masa sebelum KUHAP, keterlibatan serta pengetahuan jaksa dalam penyidikan sangat besar. Di samping itu, tidak diperlukan adanya penghubung seperti prapenuntutan. Sejak berlakunya KUHAP semakin jelas ada pemisahan fungsi antara polisi dan jaksa. Demikian halnya dengan bentuk koordinasi fungsional, seperti pemberitahuan dimulainya penyidikan, pemberitahuan dihentikannya penyidikan, permintaan perpanjangan penahanan, serta penyerahan berkas perkara apabila belum lengkap dalam tahap prapenuntutan.

\section{Penyelidikan dan Penyidikan .}

Pada saat penyidik melakukan penyidikan terhadap perkara pidana, pihak penyidik Polri langsung berkoordinasi dengan penuntut umum. Sebagai contoh terhadap penanganan kasus kejahatan seksual terhadap anak, penuntut umum dapat menilai dan memberikan masukan kepada penyidik mengenai apa saja hal-hal yang seharusnya dilakukan penyidik pada saat dilakukannya penyidikan serta pasal apa yang dapat diterapkan dalam perkara tersebut, apakah terhadap tersangka dapat dikenakan sanksi pidana dari undang-undang perlindungan anak atau Qanun Jinayat. Untuk pengendalian perkara Pidana Umum agar lebih cepat dan terarah pihak penyidik dapat langsung berkoordinasi dengan Kasi Pidum (Kepala Seksi Tindak Pidana Umum).

Penuntut umum juga memiliki kewenangan dalam hal mengubah pasal Perundang-undangan pidana yang dicantumkan oleh penyidik, dapat disimak dalam hal ini adalah merupakan letak hubungan yang tidak terpisahkan antara polisi dan penuntut umum., sehubungan dengan wewenang penyidikan Polisi. Adanya batas kewenangan tersebut dinilai tepat dan logis mengingat masalah penahanan merupakan masalah yang berkaitan dengan kemerdekaan seseorang yang berkaitan dengan Hak Asasi Manusia, namun apabila ada pihak yang kurang hati-hati dan bijaksana dalam penanganan perkara maka akan menjadi sumber penyimpangan atau penyalahgunaan wewenang. 


\section{Penuntutan Dan Pemeriksaan Pengadilan}

Dalam hal lamanya waktu penahanan setelah berkas dinyatakan lengkap oleh Jaksa atau P-21 dan telah dilakukan penyerahan tersangka dan barang bukti lamanya penahanan yang diatur dalam Qanun Aceh berbeda dengan KUHAP, dalam Qanun Hukum Acara Jinayat di pasal 24 ayat 1 dan 2 dijelaskan jangka waktu penahanan dari penyidik adalah 20 (dua puluh) hari dan dapat diperpanjang oleh penuntut umum selama 30 (tiga puluh) hari. Sedangkan di dalam KUHAP di pasal 24 ayat (1) dan (2) penahanan hanya berlaku paling lama 20 (dua puluh) hari dan dapat diperpanjang oleh penuntut umum yang berwenang untuk paling lama 40 (empat puluh) hari. Setelah lewat batas waktu penahanan tersebut penyidik harus sudah mengeluarkan tersangka dari tahanan demi hukum.

Penulis mengambil contoh kasus yang terjadi di Aceh Sigkil yaitu jarimah perkosaan terhadap anak atas nama terpidana terdakwa ABDUL MUTHOLIB SEMBIRING Bin Alm. WAHITUN(59 Tahun) telah melakukan Jarimah Pemerkosaan terhadap seseorang yang merupakan anak tirinya berinisial $A N$ yang masih berumur 7 (tujuh) tahun. Dalam Qanun hubungan tersebut masuk ke dalam Mahram, Mahram ini dalam Qanun dijabarkan dalam pasal 1 ke 25 orang yang haram dinikah selamalamanya yakni orang tua kandung dan seterusnya ke atas, orang tua tiri, anak dan seterusnya ke bawah, anak tiri, dari istri yang telah disetubuhi, saudara (kandung seayah dan seibu), saudara sesusuan, saudara ayah, saudara ibu, anak saudara, mertua (laki-laki dan perempuan), menantu (laki-laki dan perempuan).

Dalam surat dakwaannya penuntut umum mendakwakan kepada terdakwa dengan bentuk dakwaan primair subsidiair, dakwaan primair dengan pasal 49 Qanun Aceh Nomor 6 Tahun 2014 Tentang Hukum Jinayat dan dakwaan subsidiair pasal 50 Qanun Aceh Nomor 6 Tahun 2014 Tentang Hukum Jinayat.

Dalam Tuntutannya berdasarkan fakta-fakta di persidangan, didengarkan keterangan saksi-saksi serta keterangan terdakwa dan juga barang bukti. Bahwa oleh karena semua unsur dakwaan primair telah terbukti maka penuntut umum berpendapat dakwaan subsidiair tidak perlu diuraikan lagi. Penuntut umum dalam hal ini berkesimpulan bahwa terdakwa atas nama terdakwa ABDUL MUTHOLIB 
SEMBIRING Bin Alm. WAHITUN telah terbukti secara sah dan meyakinkan bersalah menurut hukum melakukan Jinayat Pemerkosaan terhadap $A N$ yang merupakan anak tirinya, sebagaimana dalam dakwaan Primair pasal 49 Qanun Aceh Nomor 6 Tahun 2014 Tentang Hukum Jinayat. Penuntut umum menuntut terdakwa supaya Hakim Mahkamah Syar'iyah Singkil menjatuhkan pidana oleh karena itu kepada terdakwa dengan uqubat penjara selama 180 (seratus delapan puluh) bulan atau 15 (lima belas) tahun dikurangi selama terdakwa berada dalam tahanan dengan perintah terdakwa tetap berada dalam tahanan.

Dalam Putusannya Mahkamah Syar'iyah Singkil Nomor 3/JN/2018/MS-Skl tanggal 25 April 2018 Mengadili Menjatuhkan Terdakwa ABDUL MUTHOLIB SEMBIRING BINALM WAHITUN telah terbukti secara sah dan meyakinkan menurut hukum melakukan jarimah pemerkosaan terhadap mahram, Menjatuhkan uqubat (pidana) Terdakwa dengan penjara selama 180 (seratus delapan puluh) bulan atau 15 (lima belas) tahun dikurangi masa penahanan yang telah dijalani oleh terdakwa.

Pada praktek di lapangan terhadap hal tersebut Mahkamah Syar'iyah mendukung dan sejalan dengan apa yang menjadi pemikiran dari penuntut umum. Selain dari jarimah-jarimah kekerasan seksual lembaga-lembaga penegak hukum tetap konsisten juga melakukan hukuman cambuk terhadap jarimah lain seperti khamr, Maisir hingga Zina.

\section{Eksekusi}

Dalam Qanun Pelaksanaan 'Uqubat adalah merupakan kewenangan dan tanggung jawab jaksa penuntut umum. Terdapat beberapa Uqubat dalam Qanun antara lain 'Uqubat denda, penjara dan cambuk. Terhadap pelaksanaan Uqubat denda dilakukan oleh jaksa dengan dikeluarkannya surat pemberitahuan kepada terpidana untuk membayar denda dengan menyetor denda kepada Baitul Mal. Dengan adanya bukti setor yang telah diterima oleh terpidana kemudian diserahkan kepada jaksa, lalu jaksa akan mengeluarkan surat pernyataan bahwa hukuman tersebut sudah dilaksanakan. Namun apabila terpidana atau terhukum tidak membayarnya dalam tempo waktu satu bulan maka jaksa dapat menyita harta kekayaan terhukum. 
Jaksa sebagai eksekutor membacakan berita acara pelaksanaan hukum cambuk dan pelaksananya adalah algojo yang disiapkan dari wilayatul hisbah di mana identitas dari algojo tersebut dirahasiakan. Para algojo ini telah dibekali dengan petunjuk teknis tata cara pencambukan. Sebelum dilaksanakannya eksekusi cambuk akan didahului dengan doa serta pembacaan ayat suci Al Quran setelah itu dilanjutkan dengan ceramah atau siraman rohani terkait dengan jarimah yang dilakukan oleh terhukum. Terhukum harus dalam kondisi sehat dan dapat menjalani hukuman cambuk menurut keterangan dokter, setelah dilakukan cek kesehatan oleh tim medis lalu satu persatu terhukum dipanggil ke atas panggung untuk dilakukan pencambukan sesuai dengan putusan dari mahkamah syar'iyah. Cambuk terbuat dari rotan dengan diameter $0,75 \mathrm{~cm}$ dan panjang 1 meter, diayunkan kebagian punggung si terhukum atas perintah jaksa.

Dalam pelaksanaan Qanun hukum jinayah ini masih terdapat banyak hambatan serta kendala antara lain adalah terhadap eksekusi cambuk ini banyak memakan waktu menunggu sebelum dilakukannya eksekusi, karena untuk melaksanakan eksekusi cambuk sang eksekutor (jaksa) harus berkoordinasi dengan pihak terkait seperti Ketua Mahkamah Syar'iyah, Kepala Dinas Kesehatan dan Instansi yang membawahi Wilayatul Hisbah kota setempat dan kepala instansi yang membawahi wilayatul hisbah memberitahukan kesiapan petugas pencambuk pada jaksa sebelum waktu pencambukan. Wilayatul hisbah inilah yang nantinya mengatur di mana tempat dan kapan waktu eksekusi tersebut dilaksanakan. Tidak jarang akibat hal tersebut menyebabkan masa penahanan pelaku sudah habis. Selain itu belum adanya Lembaga Permasyarakatan (LAPAS) atau Rumah tahanan (RUTAN) khusus pelaku jarimah qanun. Untuk pelaku jarimah qanun masih menggunakan sel umum. Hal ini menjadi kekhawatiran karena bercampurnya para pelaku qanun dengan pelaku tindak kejahatan lain seperti pelaku pembunuhan, narkotika dan para pelaku kejahatan kelas berat lainnya. ${ }^{19}$ Selain itu selama ini pelaku yang dihukum dalam qanun di dalam penjara biaya makan juga yang menanggung adalah pihak

${ }^{19}$ Fauziati, Ketua Mahkamah Syar 'iyah Singkil, wawancara tanggal 29 Januari 2019. 
rutan, belum ada aturan qanun mengenai anggaran khusus dalam hal ini masih menjadi kelemahan dalam qanun.

Dengan pelaksanaan sanksi pidana cambuk ini menjadikan beban yang harus ditanggung pemerintah lebih murah dibandingkan dengan jenis hukuman lainya seperti yang dikenal dalam sistem KUHP sekarang ini.

\section{Kesimpulan}

Bila diambil dari pembahasan diatas, Kedudukan Qanun ini dapat diakui dalam hierarki undang-undang di Indonesia yang sejajar dengan perda. Diakuinya Qanun ini artinya Qanun memiliki kekuatan hukum yang mengikat. NAD merupakan wilayah khusus yang diberikan oleh Pemerintah Pusat sebagai pelaksanaa Undangundang di wilayah otonomi khusus. Namun tetap mengedepankan aqidah syariah.

Sepanjang ada dugaan perbuatan pidana dari tersangka, apabila suatu tindak pidana tersebut memenuhi unsur pasal yang terdapat dalam Qanun Jinayat, maka wajib diterapkan sanksi pidana dari Undang-undang nomor 6 Tahun 2014 tentang Qanun Jinayat. Mengingat adanya hal-hal yang sudah merupakan kompetensi absolut, mengenai pengadilan mana yang berwenang untuk mengadili, dalam hal ini adalah Mahkamah Syar'iyah. Namun masih terdapat beberapa kelemahan dalam Qanun itu sendiri.

Terhadap perkara ini Jaksa sebagai penuntut umum lebih mengarahkan tuntutannya dalam uqubat penjara, tidak dengan cambuk. Hukuman ini dirasa akan lebih lama dan memiliki efek jera bagi pelaku.

\section{Daftar Bacaan}

\section{Buku}

Adami Chazawi, Pelajaran Hukum Pidana (Raja Grafindo 2001).

Barda Nawawi Arief, Bunga Rampai Kebijakan Hukum Pidana (Citra Aditya Bakti 2002).

Wahyono P, Indonesia Negara Berdasarkan Atas Hukum (Ghalia Indonesia 1986). 
Yunus M, Kamus Arab-Indonesia (Hidakarya Agung 1989).

Zulkarnain Lubis dan Bakti Ritonga, Dasar-Dasar Hukum Acara Jinayah (Prenamedia Grup 2016).

\section{Laman}

Hasyim, 'Qanun Jinayat Berlaku Untuk Semua Orang Di Aceh' (Serambinews.com, 2014) <https://aceh.tribunnews.com/2014/04/19/qanun-jinayat-berlakuuntuk-semua-orang-di-aceh $>$ accessed 1 January 2019.

\section{Perundang-undangan}

Undang-Undang Dasar 1945.

Kitab Undang-Undang Hukum Pidana.

Kitab Undang-Undang Hukum Acara Pidana.

Undang-Undang Nomor 16 Tahun 2004 Tentang Kejaksaan Republik Indonesia.

Undang-Undang Nomor 35 Tahun 2014 Tentang Perlindungan Anak.

Qanun Aceh Nomor 6 Tahun 2014 Tentang Hukum Jinayat.

HOW TO CITE: Virdis Firmanillah Putra Yuniar, 'Penegakan Hukum dalam Tindak Pidana Pemerkosaan Terhadap Anak Berdasarkan Qanun Jinayat Aceh' (2019) Vol. 2 No. 2 Media Iuris. 